\title{
Intrathecal landiolol inhibits nociception and spinal c-Fos expression in the mouse formalin test
}

\author{
[Le landiolol intrathécal inhibe la nociception ainsi que l'expression rachidienne
} de c-Fos lors du test de formaline chez la souris]

Hang Zhao MD, Takeshi Sugawara MD, Shihiro Miura MD, Tetsuya Iijima MD, Satoshi Kashimoto MD PhD

Purpose: The purpose of this study was to determine if intrathecal landiolol, a $\beta_{1}$-blocker, can modulate formalininduced nociception and spinal c-Fos expression in mice, in the absence of anesthesia.

Methods: Thirty-two mice were randomly assigned to one of four groups: the control group $(n=8)$ received intrathecal normal saline $10 \mu \mathrm{L}$, while the other three groups $(n=8$ for each) received intrathecal landiolol at escalating doses of 250 $\mu \mathrm{g} \cdot \mathrm{kg}^{-1}, 500 \mu \mathrm{g} \cdot \mathrm{kg}^{-1}$ and $750 \mu \mathrm{g} \cdot \mathrm{kg}^{-1}$ respectively, immediately after induction of anesthesia with isoflurane. After awakening, inflammatory pain was induced by $10 \mu \mathrm{L}$ of $5 \%$ formalin solution injected into the dorsal surface of the right hind paw. The nociceptive behaviours including licking, biting and lifting of the injected paw were cumulatively recorded as seconds of behaviours/min during phase I (0-10 min) and phase II (10-45 $\mathrm{min})$. The c-Fos protein expressions in the spinal dorsal horn were detected with immunohistochemical techniques in the control and landiolol $750 \mu \mathrm{g} \cdot \mathrm{kg}^{-1}$ groups.

Results: Compared to the control group, intrathecal injection of landiolol $750 \mu \mathrm{g} \cdot \mathrm{kg}^{-1}$ significantly decreased pain-related behaviours in phase I, while intrathecal landiolol $250 \mu \mathrm{g} \cdot \mathrm{kg}^{-1}$, $500 \mu \mathrm{g} \cdot \mathrm{kg}^{-1}$ and $750 \mu \mathrm{g} \cdot \mathrm{kg}^{-1}$ significantly decreased pain-related behaviours in phase II during the formalin test. The numbers of c-Fos immunoreactive nuclei in the $\mathrm{L} 5$ spinal dorsal horn were significantly lower in the landiolol $750 \mu \mathrm{g} \cdot \mathrm{kg}^{-1}$ group compared to the control group (landiolol $750 \mu \mathrm{g}^{\mathrm{kg}} \mathrm{g}^{-1} 2.4 \pm \mathrm{I}$.I vs control $9.2 \pm 3.9 ; P<0.01)$.

Conclusion: The present study indicates that intrathecally administered landiolol produces significant antinociceptive effects in the formalin test. Although further studies exploring the detailed mechanism are needed, these data suggest a potential role of $\beta_{1}$-adrenoreceptors in spinal nociceptive processing.

CAN J ANESTH $2007 / 54: 3 /$ pp 201-207
Objectif : Le but de cette étude était de déterminer si le landiolol intrathécal, un bloquant $\beta$, pouvait moduler la nociception induite par la formaline et l'expression rachidienne de c-Fos chez la souris non anesthésiée.

Méthodes : Après randomisation, trente-deux souris ont été attitrées chacune à l'un des quatre groupes suivants : le groupe témoin $(n=8)$ a reçu $10 \mu \mathrm{L}$ d'une solution de salin physiologique intrathécal, les trois autres groupes ( $n=8$ chacun) ont reçu du landiolol intrathécal à doses croissantes de $250 \mu \mathrm{g} \cdot \mathrm{kg}^{-1}, 500 \mu \mathrm{g} \cdot \mathrm{kg}^{-1}$ et $750 \mu \mathrm{g} \cdot \mathrm{kg}^{-1}$ respectivement, immédiatement après l'induction de l'anesthésie avec isoflurane. Après le réveil, une douleur inflammatoire a été provoquée avec $10 \mu \mathrm{L}$ d'une solution de formaline $5 \%$ injectée dans la surface dorsale de la patte postérieure droite. Les comportements nociceptifs, incluant le léchage, les morsures et l'élévation de la patte injectée ont été enregistrés cumulativement en tant que secondes de comportement / min durant la phase I (0$10 \mathrm{~min}$ ) et la phase II (10-45 min). Les expressions protéiniques de c-Fos dans la corne supérieure dorsale ont été détectées à l'aide de techniques immunohistochimiques dans les groupes témoin et landiolol $750 \mu \mathrm{g} \cdot \mathrm{kg}^{-1}$.

Résultats : Par rapport au groupe témoin, l'injection intrathécale de landiolol $750 \mu \mathrm{g} \cdot \mathrm{kg}^{-1}$ a diminué de façon significative les comportements liés à la douleur pendant la phase I, alors que l'administration intrathécale de landiolol $250 \mu \mathrm{g} \cdot \mathrm{kg}^{-1}, 500 \mu \mathrm{g} \cdot \mathrm{kg}^{-1}$ et 750 $\mu \mathrm{g} \cdot \mathrm{kg}^{-1}$ a diminué de façon significative les comportements liés à la douleur dans la phase II durant le test à la formaline. Le nombre de noyaux immuno-réactifs de c-Fos dans la corne supérieure dorsale à $L 5$ était significativement plus bas dans le groupe landiolol 750 $\mu \mathrm{g} \cdot \mathrm{kg}^{-1}$ que dans le groupe témoin (landiolol $750 \mu \mathrm{g} \cdot \mathrm{kg}^{-1}$ 2,4 $\pm \mathrm{I}, \mathrm{I}$ vs témoin $9,2 \pm 3,9 ; P<0,01)$.

Conclusion: Cette étude démontre que l'injection intrathécale de landiodol a des effets antinociceptifs significatifs avec le test à la formaline. Bien que d'autres études explorant ce mécanisme soient nécessaires, ces données suggèrent un rôle potentiel des adréno-récepteurs $\beta$, dans le traitement des stimuli nociceptifs au niveau rachidien.

From the Department of Anaesthesiology, Faculty of Medicine, University of Yamanashi, Yamanashi, Japan. Address correspondence to: Dr. Satoshi Kashimoto, Associate Professor, 1110 Shimokato, Chuo, Yamanashi, Japan 409-3898.

Phone: +81-55-2739690; Fax: +81-55-2736755; E-mail: satoshik@yamanashi.ac.jp

This study was supported by the Department of Anesthesiology, Faculty of Medicine, University of Yamanashi. Accepted for publication November 14, 2006.

Revision accepted November 28, 2006. 
S HORT-ACTING $\beta_{1}$-adrenergic receptor antagonists $\left(\beta_{1}\right.$-blockers $)$ have been widely used in clinical anesthesia for their antihypertensive and anti-tachycardia effects. They are effective in blunting adrenergic responses to several perioperative stimuli such as laryngoscopy, intubation and extubation. ${ }^{1-4}$ In addition, the sedative properties of these compounds may decrease anesthetic requirements ${ }^{5-8}$ and reduce bispectral index, a value reflecting activity of the cerebral cortex and levels of consciousness. ${ }^{3}$ In recent years, there have been several reports identifying the antinociceptive and analgesic effects of $\beta_{1}$-blockers in both animal and human studies. For example, Chia et al. ${ }^{9}$ reported that intraoperative iv infusion of esmolol reduced not only the end-tidal isoflurane concentrations necessary for maintenance of general anesthesia, but also the total morphine consumption in postoperative patient controlled analgesia. Davidson et al. ${ }^{10}$ also demonstrated that $i v$ esmolol reduced pain behaviour in the rat with formalin testing. Several possible mechanisms of $\beta_{1}$-blockers' nociception have been proposed. However, there has been no direct in vivo evidence in animal experimentation showing antinociceptive effects of these drugs.

Landiolol is a newer drug than esmolol which has greater $\beta_{1}$-adrenoceptor selectivity and inhibition potency. ${ }^{11}$ As a result of its pharmacological attributes, this study was undertaken to test the hypothesis that intrathecally administered landiolol would reduce pain behaviour and c-Fos expression in the spinal cord of the mouse using the formalin test. The c-Fos protein is a pain-related marker which rapidly expresses neuronal responses to stimulation. ${ }^{12,13}$

\section{Methods}

This protocol was reviewed and approved by the Institutional Animal Care and Use Committee of the University of Yamanashi, Yamanashi, Japan.

\section{Animals}

Eight-week-old male Std ddY mice weighing 25-30g were used to eliminate possible sex and age differences in reaction to noxious stimuli. The animals were housed in standard cages $(33 \times 23 \times 12 \mathrm{~cm}, 2-4$ mice/ cage) with free access to food and water prior to the experiments. They were maintained under controlled conditions of temperature $\left(23 \pm 0.5^{\circ} \mathrm{C}\right)$, humidity $(50 \%)$ and lighting (lights on from 6 a.m. to 6 p.m.).

\section{Drugs}

Landiolol hydrochloride (ONO-1101) was obtained from Ono Pharmaceutical Co. (Osaka, Japan) provided as powder. It was dissolved in $0.9 \% \mathrm{NaCl}$ and stored at $-20^{\circ} \mathrm{C}$ in a refrigerator before use.

\section{Formalin test and mice behaviour evaluation}

The mice formalin test was essentially the same as reported by Hunskaar and Hole. ${ }^{14}$ Approximately 30 min before injection, mice were individually placed in another transparent observation cage of the same size for adaptation. Mirrors were placed on sides opposite the observer for easy confirmation of pain-related behaviours. Then, the mice were removed from the chamber to receive anesthesia with $2 \%$ isoflurane, followed by intrathecal injection of normal saline 10 $\mu \mathrm{L}$ or equivalent volumes of landiolol at escalating doses of $250 \mu \mathrm{g} \cdot \mathrm{kg}^{-1}, 500 \mu \mathrm{g} \cdot \mathrm{kg}^{-1}$ and $750 \mu \mathrm{g} \cdot \mathrm{kg}^{-1}$ respectively. Immediately after intrathecal injection, the mice were awakened and a bolus of $10 \mu \mathrm{L}$ of $5 \%$ formalin solution was injected into the interplantar dorsal surface of the right hind paw using a microsyringe (Hamilton co. NV, USA) attached to a 30 $\mathrm{G}$ needle. Then, each mouse was returned to the observation cage and the time spent by each animal showing pain-related behaviours was measured by a stopwatch in each five-minute epoch for $45 \mathrm{~min}$ after formalin injection. The trained observer was blinded to the intrathecal solutions injected. The nociceptive behaviours consisted of flickering, lifting, biting and licking of the hind paw. The nociceptive responses after formalin injection were documented for two periods: phase I (0-10 $\mathrm{min})$ and phase II (10-45 $\mathrm{min})$.

\section{Intrathecal injection}

Intrathecal injections were performed as described by Hylden and Wilcox. ${ }^{15}$ The $30-\mathrm{G}$ needle was inserted into the intervertebral space between the L5 and L6 levels of the spinal cord and intrathecal location of the needle tip was confirmed by a characteristic flick of the tail. In the pilot study, a volume of $5 \mu \mathrm{L}$ of $2 \%$ lidocaine was injected intrathecally into five mice which elicited immediate hind limb paralysis that lasted for about ten minutes.

\section{Tissue preparation and c-Fos immunohistochemistry}

The c-Fos immunocytochemical staining method was similar to that described by Kobelt et al. ${ }^{16}$ with minor modifications. Briefly, one hour after formalin injection, mice in the landiolol $750 \mu \mathrm{g} \cdot \mathrm{kg}^{-1}$ and normal saline groups were anesthetized with isoflurane and oxygen and perfused intracardially with $20 \mathrm{~mL}$ normal saline followed by $20 \mathrm{~mL}$ of $4 \%$ paraformaldehyde in phosphate buffered saline (PBS). After the animal's neck and limbs stiffened, the spinal cords were removed and postfixed overnight with 


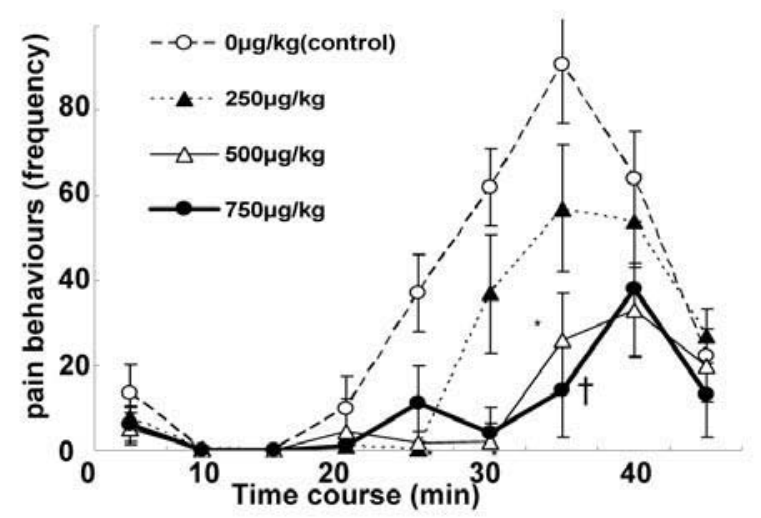

FIGURE 1 Time-course of formalin-induced pain behaviour in mice treated with intrathecal landiolol $0 \mu \mathrm{g} \cdot \mathrm{kg}^{-1}$ (control), $250 \mu \mathrm{g} \cdot \mathrm{kg}^{-1}, 500 \mu \mathrm{g} \cdot \mathrm{kg}^{-1}$, and $750 \mu \mathrm{g} \cdot \mathrm{kg}^{-1}$ after dorsal injection of $5 \%$ formalin solution $10 \mu \mathrm{L}$ into the right hind paw. ${ }^{*} P<0.05, \dagger P<0.01$, vs control group.

the same perfusion solution, and then submerged overnight in 4\% paraformaldehyde in PBS containing $30 \%$ sucrose, before slicing. The lumbar spinal cord was embedded in optimal cutting compound (O.C.T. compound, Sakura Finetechnical, Tokyo, Japan) and cut into $20-\mu \mathrm{m}$-thick frozen serial sections. The tissue sections were mounted on MAS-coated glass slides and incubated in $1 \% \mathrm{w} / \mathrm{v}$ sodium borohydride (Wako Pure Chemical Industries, Tokyo, Japan) in PBS for $15 \mathrm{~min}$. Sodium borohydride was used to minimize aldehyde-induced autofluorescence in the tissue. Then sections were incubated for two hours at room temperature in a blocking solution of $10 \%$ bovine serum albumin in PBS with $0.3 \%$ TritonX100. Sections were incubated $24 \mathrm{hr}$ at room temperature in a primary antibody to c-Fos (1:10,000 rabbit polyclonal antibody to c-Fos; Oncogene Research Product, San Diego, CA, USA). After incubation, tissue sections were rinsed three times with PBS and incubated in a secondary anti-rabbit antibody (1:400) conjugated with fluorescent marker FITC (sc-2012; Santa Cruz Biotechnology, Santa Cruz, CA, USA) for four hours at room temperature. Then, those sections were washed with PBS three times. Finally, as the counterstaining of cell chromatin, sections were incubated in dilute propidium iodide solutions at $2.5 \mu \mathrm{g} \cdot \mathrm{mL}^{-1}$ (Sigma-Aldrich, St. Louis, MO, USA) with PBS for $15 \mathrm{~min}$, and washed in PBS three times, then immersed with S-2828 antifading reagent in glycerol/PBS (Molecular Probes, Eugene, OR, USA) and cover slipped. Sections were observed using a mirror unit U-MWB2 for FITC and

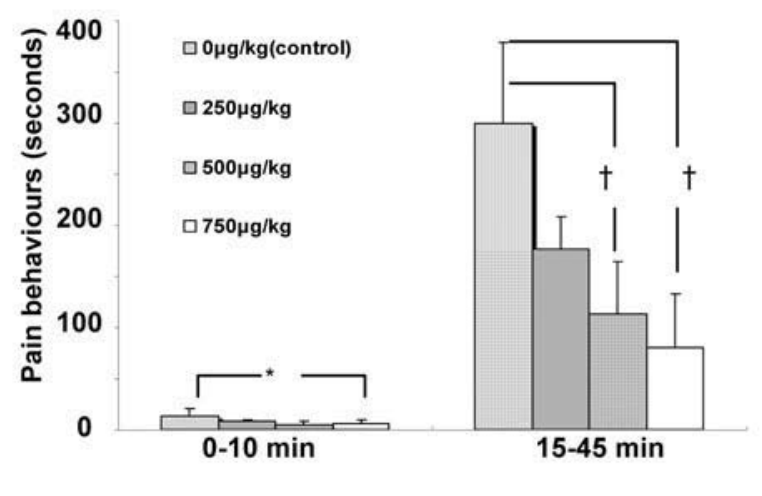

FIGURE 2 Formalin induced pain behaviours during phase I and phase II. Each block represents the mean of eight animals, and the vertical bars indicate the SEM. ${ }^{*} P<0.05$, $\dagger P<0.01$, vs control group.

U-MWG2 for propidium iodide with a fluorescence microscope (Olympus BX51-FLA, Tokyo, Japan) and photographed with an Olympus DP70 camera. The above antibodies were controlled with staining the NIH 3T3 (RCB1862, Riken bio resource center, Tokyo, Japan) fibroblast cultures stimulated with $20 \%$ fetal calf serum in Dulbecco's modified eagle medium after serum starvation according to the method by Vriz et al. ${ }^{17}$ Omission of the primary antibody was used as a negative control and resulted in no staining.

\section{Counting of c-Fos protein immunoreactive nuclei}

For the quantification of the c-Fos protein expression in the spinal cord, we determined the number of $\mathrm{c}^{-}$ Fos-immunoreactive (IR) nuclei in the L5 segment of the spinal cord. The amount of c-Fos-IR nuclei in the dorsal horn lamina I and II of L5 spinal cord was counted visibly. Spinal laminae were defined as described by Weng et al. ${ }^{18}$

\section{Statistical analysis}

The behavioural data are presented as means \pm standard error of the mean of $n$ experiments. Statistical analysis was carried out using the non-parametric KruskalWallis test followed by Tukey's test to compare accumulated pain behaviours at each time epoch and total pain behaviours during phase I and phase II among the groups. The Student's $t$ test was used to compare c-Fos-IR expression of L5 spinal cord in the landiolol $750 \mu \mathrm{g} \cdot \mathrm{kg}^{-1}$ group and the normal saline group. A $P$ value $<0.05$ was considered statistically significant. 


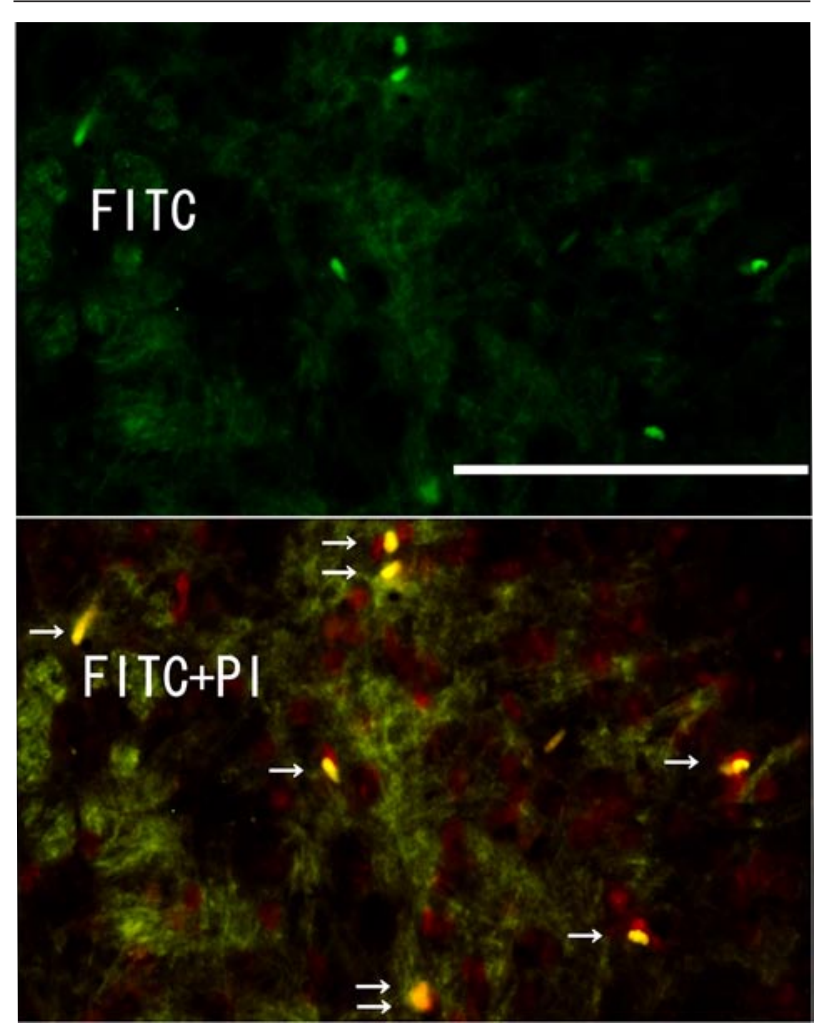

FIGURE 3A Typical photomicrograph of a $20-\mu \mathrm{m}$ thin section of laminae I and II of the L5 dorsal horn of a "control" mouse. Green: FITC -labelled c-Fos protein. Red: propidium iodide (PI), which is marker of chromatin. Yellow: merged images $(\rightarrow)$. c-Fos-immunoreactive (IR) nuclei are shown as yellow spots. Many c-Fos-IR nuclei were expressed by formalin injection. (Scale bar $=100 \mu \mathrm{m}$ ).

\section{Results}

The intraplantar injection of $10 \mu \mathrm{L}$ of $5 \%$ formalin solution into the dorsal surface of the right hind paw produced a typical biphasic nociceptive response. The first phase started immediately after formalin injection and lasted for about ten minutes, while the second phase was much longer, starting from 15 min after the injection and lasting for about $30 \mathrm{~min}$. There were no significant differences in the frequencies of the first phase nociceptive behaviours among the groups. However, in the second phase, the frequencies of nociceptive behaviours in the landiolol $250 \mu \mathrm{g} \cdot \mathrm{kg}^{-1}$, $500 \mu \mathrm{g} \cdot \mathrm{kg}^{-1}$ and $750 \mu \mathrm{g} \cdot \mathrm{kg}^{-1}$ groups were less than that in the control group (Figure 1). Figure 2 shows the total time of nociceptive behaviours. In the first phase, the total time of nociceptive behaviours was significantly less in the landiolol $750 \mu \mathrm{g} \cdot \mathrm{kg}^{-1}$ group compared to the control group (landiolol $750 \mu \mathrm{g} \cdot \mathrm{kg}^{-1}$

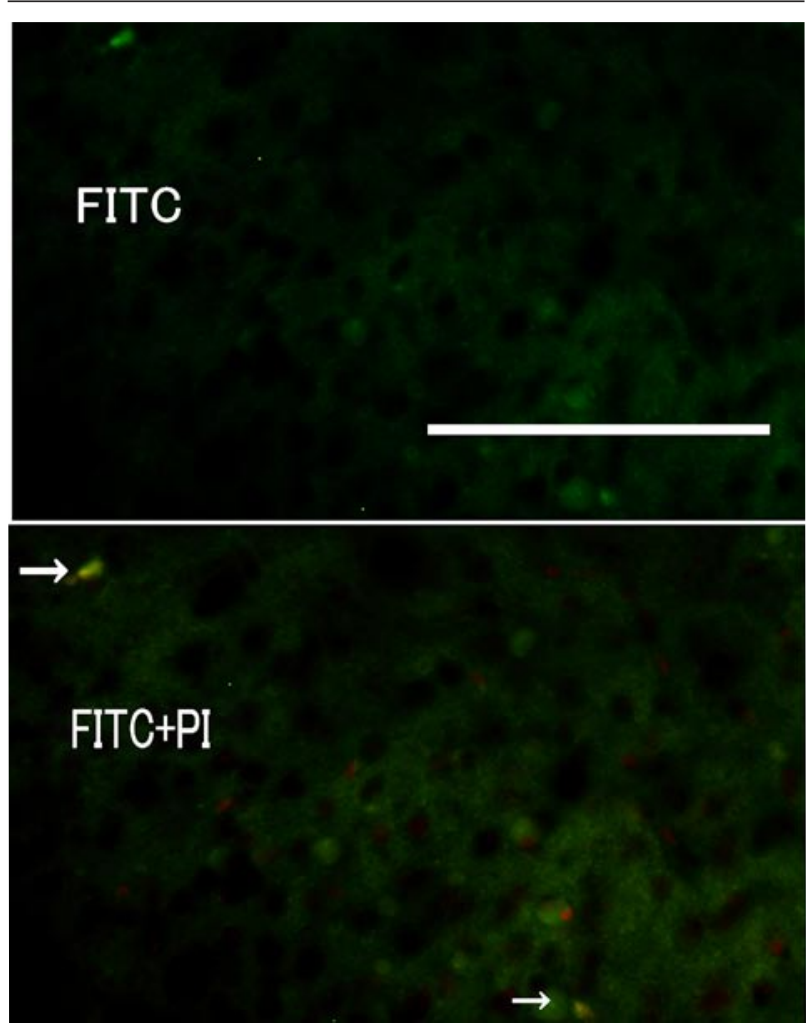

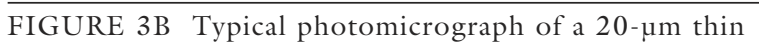
section of laminae I and II of the L5 ipsilateral dorsal horn of a representative intrathecal landiolol $750 \mu \mathrm{g} \cdot \mathrm{kg}^{-1}$ mouse. Green: FITC-labelled c-Fos protein. Red: propidium iodide $(\mathrm{PI})$, which is marker of chromatin. Yellow: merged images $(\rightarrow)$. c-Fos-immunoreactive (IR) nuclei are shown as yellow spots. Few c-Fos-IR nuclei were expressed in the ipsilateral dorsal horn. (Scale bar $=100 \mu \mathrm{m})$.

group $5.6 \pm 3.9 \mathrm{sec} v s$ control group $13.6 \pm 6.7 \mathrm{sec}$; $P<0.05)$. In the second phase, the total time of nociceptive behaviours was significantly less in the landiolol $500 \mu \mathrm{g} \cdot \mathrm{kg}^{-1}$ and $750 \mu \mathrm{g} \cdot \mathrm{kg}^{-1}$ groups than in the control group (landiolol $750 \mu \mathrm{g} \cdot \mathrm{kg}^{-1}$ group $80.3 \pm 53 \mathrm{sec}$, landiolol $500 \mu \mathrm{g} \cdot \mathrm{kg}^{-1}$ group $113.7 \pm$ $50.6 \mathrm{sec} v s$ control group $300 \pm 78.7 \mathrm{sec} ; P<0.05$ ). Mice that received injection of normal saline instead of formalin into the right hind paw did not show any pain-related behaviours (data not shown). In addition, the landiolol group mice did not show any differences except for the pain-related behaviours compared to the control mice.

To test whether landiolol would reduce expression of c-Fos, a neural marker of pain, in the mice formalin test, in situ fluorescence immunohistochemistry was performed in both landiolol $750 \mu \mathrm{g} \cdot \mathrm{kg}^{-1}$ and control 


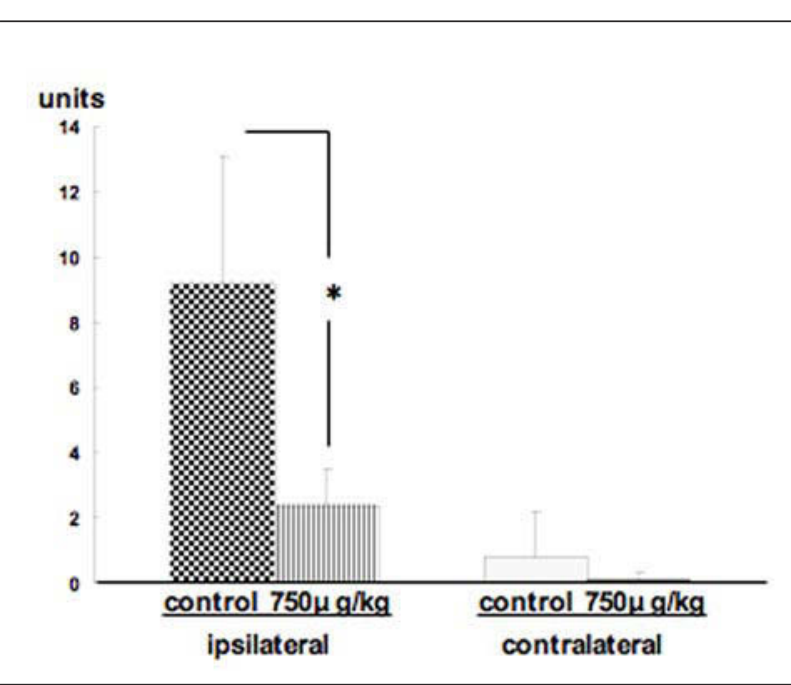

FIGURE 4 Changes in total numbers of c-Fosimmunoreactive nuclei in laminae I and II of the L5 dorsal horn one hour after $10 \mu \mathrm{L} 5 \%$ formalin solution was injected into the hind paw. Intrathecal landiolol 750 $\mu \mathrm{g} \cdot \mathrm{kg}^{-1}$ significantly suppressed $\mathrm{c}$-Fos protein expression in the ipsilateral dorsal horn. ${ }^{*} P<0.01$ ps control group.

groups. Typical photomicrographs of IR Fos neurons in the L5 dorsal horn are shown in Figures $3 \mathrm{a}$ and $3 \mathrm{~b}$, and the total numbers of c-Fos-IR nuclei in the control and landiolol $750 \mu \mathrm{g} \cdot \mathrm{kg}^{-1}$ groups are shown in Figure 4. The c-Fos- IR nuclei expression was rarely observed in the dorsal horn of contralateral sides in both the landiolol $750 \mu \mathrm{g} \cdot \mathrm{kg}^{-1}$ and control groups. In contrast, on the ipsilateral sides, many c-Fos-IR nuclei were detected predominantly in the superficial laminae I and II of the spinal dorsal horn in the control group, while there were significantly fewer c-Fos-IR nuclei in the landiolol $750 \mu \mathrm{g} \cdot \mathrm{kg}^{-1}$ group (landiolol 750 $\mu \mathrm{g} \cdot \mathrm{kg}^{-1}$ group $2.4 \pm 1.1 \mathrm{vs}$ control group $9.2 \pm 3.9$; $P<0.01)$.

\section{Discussion}

Although there are reports defining the antinociceptive effects of $\beta_{1}$-blockers, none has specifically documented direct evidence of action. Our study is the first to provide the evidence that the ultra-short-acting $\beta_{1}$ receptor antagonist, landiolol, decreases both the pain-related behaviour and the expression of c-Fos-IR nuclei in the spinal cord of the mouse in response to the formalin test.

Ultra-short-acting $\beta_{1}$-blockers have been widely used to blunt excessive hemodynamic changes in clinical anesthesia. ${ }^{1-4}$ The advantages of using landiolol in clinical anesthesia include that it is very short-acting and highly selective for $\beta_{1}$ receptors, ${ }^{11}$ thus rendering easy titration and less side effects such as asthma or peripheral vasoconstriction compared to other longer-acting $\beta$ blockers. As landiolol is metabolized very quickly by serum pseudochorinesterase and carboxyesterase in the liver to an inactive metabolite with a short half-life, it is reasonable to assume that most of the intrathecal landiolol will undergo decomposition and excretion before the drug diffuses into the blood and takes systemic pharmacological effect. In fact, according to our observation, the landiolol group mice did not show any differences except for the pain-related behaviours compared to the control mice.

In a typical formalin test, pain-related behaviours are defined by the mouse's behaviour to shake or hold the paw in the air, or to groom, lick or chew the paw repeatedly. There are two phases of painrelated behaviours after formalin injection which involve a complex series of events. The first phase lasts between five to ten minutes and is attributed to direct chemical stimulation of chemosensitive nociceptors. ${ }^{19}$ The second phase starts from 15 to 20 min after injection and is believed to be associated with the release of local inflammatory mediators that lead to spinal dorsal horn neuronal sensitization and subsequent activation of the nociceptors. ${ }^{14,20}$ In the present study, landiolol influenced the second phase since it suppressed the second phase response in a dose-dependent manner, although it reduced the first phase behaviours significantly only at the highest dose $\left(750 \mu \mathrm{g} \cdot \mathrm{kg}^{-1}\right)$. In addition, as landiolol is ultra-short acting, it may mainly exert antinociceptive effects for the first $30 \mathrm{~min}$ even in the higher dose groups.

There have been numerous reports in the literature relating to expression of the immediate-early-gene product c-Fos as a well-established neuronal marker in response to noxious stimulation. Nociceptive reflexes and other pain-related behaviours similarly modify c-Fos expression in the spinal dorsal horn. ${ }^{12,13}$ The noxious stimulus-evoked c-Fos expression is suppressed by administration of analgesic drugs including morphine, ${ }^{21,22}$ indomethacin, ${ }^{23}$ and ketoprofen, ${ }^{24}$ as well as by other drugs that interfere with nociceptive processing at the spinal level such as noradrenaline, ${ }^{25}$ and N-methyl-D-asparate receptor antagonists. ${ }^{26,27}$ We observed that c-Fos-IR nuclei were expressed in the spinal dorsal horn of L5 one hour after formalin injection into the interplantar dorsal surface of the right hind paw, and landiolol markedly inhibited the formalin-evoked expression of c-Fos-IR nuclei in the superficial layers of the ipsilateral dorsal horn of the spinal cord. Suppression of spinal c-Fos-IR expression 
clearly indicates that landiolol has antinociceptive effects, since peripheral noxious stimulation is mediated initially to neurons in laminae I and II of the dorsal horn. ${ }^{28}$

What is the mechanism of $\beta_{1}$-blocker-induced antinociceptive effects? Berridge et al. ${ }^{29}$ have shown that $\beta$ receptor antagonists may exert their antinociceptive effects by blocking $\beta$ receptors within the reticular formation. Hageluken et al. ${ }^{30}$ reported that lipophilic $\beta$ receptor antagonists might inhibit nociceptive signal transduction through activation of inhibitory $\mathrm{G}$ protein in the spinal cord. One report indicates that propranolol, esmolol, landiolol and lidocaine blocked tetrodotoxin-resistant $\mathrm{Na}^{+}$channels in the rat spinal dorsal root ganglions dose-dependently, but required very high landiolol concentrations to achieve this effect. $^{31}$ Therefore, blocking tetrodotoxin-resistant $\mathrm{Na}^{+}$channels might be one mechanism related to the analgesic effects of landiolol. Nevertheless, there is limited experimental evidence to fully explain the antinociceptive effects of landiolol and other shortacting $\beta_{1}$ blockers and the mechanism of analgesic efficacy remains to be elucidated.

In conclusion, we have shown that the ultrashort-acting $\beta_{1}$ receptor antagonist, landiolol, dosedependently decreases pain-related behaviour in the mouse formalin test. We also demonstrate that landiolol reduces c-Fos-IR expression in the dorsal horn of the spinal cord after formalin injection. Although further studies exploring the complicated mechanisms of analgesic efficacy are warranted, the results of this investigation indicate that landiolol provides antinociceptive effects at the spinal level.

\section{References}

1 Miller DR, Martineau RJ, Wynands JE, Hill J.

Bolus administration of esmolol for controlling the haemodynamic response to tracheal intubation: the Canadian Multicentre Trial. Can J Anaesth 1991; 38: 849-58.

2 Fubrman TM, Ewell CL, Pippin WD, Weaver JM. Comparison of the efficacy of esmolol and alfentanil to attenuate the hemodynamic responses to emergence and extubation. J Clin Anesth 1992; 4: 444-7.

3 Oda $\Upsilon$, Nishikawa K, Hase I, Asada A. The shortacting $\beta \mathrm{l}$-adrenoceptor antagonists esmolol and landiolol suppress the bispectral index response to tracheal intubation during sevoflurane anesthesia. Anesth Analg 2005; 100: 733-7.

4 Wilson ES, McKinlay S, Crawford JM, Robb HM. The influence of esmolol on the dose of propofol required for induction of anesthesia. Anaesthesia 2004; 59: 122-6.
5 Johansen JW, Flaishon R, Sebel PS. Esmolol reduces anesthetic requirement for skin incision during propofol/nitrous oxide/morphine anaesthesia. Anesthesiology 1997; 86: 364-71.

6 Jobansen JW, Schneider G, Windsor AM, Sebel PS. Esmolol potentiates reduction of minimum alveolar isoflurane concentration by alfentanil. Anesth Analg 1998; 87: 671-6.

7 Smith I, Van Hemelrijck J, White PF. Efficacy of esmolol versus alfentanil as a supplement to propofolnitrous oxide anesthesia. Anesth Analg 1991; 73 : 540-6.

8 Takizawa D, Saito S, Sato E, Hiraoka H, Kunimoto F, Goto $F$. Influence of landiolol on the dose requirement of propofol for induction of anesthesia. Fundam Clin Pharmacol 2005; 19: 597-9.

9 Chia Y, Chan MH, Ko NH, Lin K. Role of betablockade in anaesthesia and postoperative pain management after hysterectomy. Br J Anaesth 2004; 93: 799-805.

10 Davidson EM, Doursout MF, Szmuk P, Chelly JE. Antinociceptive and cardiovascular properties of esmolol following formalin injection in rats. Can J Anesth 2001; 48: 59-64.

11 Atarashi H, Kuruma A, Yashima M, et al. Pharmacokinetics of landiolol hydrochloride, a new ultra-short-acting beta-blocker, in patients with cardiac arrhythmias. Clin Pharmacol Ther 2000; 68: 143-50.

12 Hunt SP, Pini A, Evan G. Induction of c-fos-like protein in spinal cord neurons following sensory stimulation. Nature 1987; 328: 632-4.

13 Harris JA. Using c-fos as a neural marker of pain. Brain Res Bull 1998; 45: 1-8.

14 Hunskaar $S$, Hole $K$. The formalin test in mice: dissociation between inflammatory and noninflammatory pain. Pain 1987; 30: 103-14.

15 Hylden JL, Wilcox GA. Intrathecal morphine in mice: a new technique. Eur J Pharmacol 1980; 67: 313-6.

16 Kobelt P, Tebbe JJ, Tjandra I, et al. Two immunocytochemical protocols for immunofluorescent detection of c-Fos positive neurons in the rat brain. Brain Res Brain Res Protoc 2004; 13: 45-52.

17 Vriz S, Lemaitre JM, Leibovici M, Thierry N, Mechali $M$. Comparative analysis of the intracellular localization of c-Myc, c-Fos, and replicative proteins during cell cycle progression. Mol Cell Biol 1992; 12: 3548-55.

18 Weng HR, Mansikka H, Winchurch R, Raja SN, Dougherty PM. Sensory processing in the deep spinal dorsal horn of neurokinin-1 receptor knockout mice. Anesthesiology 2001; 94: 1105-12.

19 Tjolsen A, Berge OG, Hunskaar S, Rosland JH, Hole K. The formalin test: an evaluation of the method. Pain 1992; 51: 5-17. 
20 Porro CA, Cavazzuti M. Spatial and temporal aspects of spinal cord and brainstem activation in the formalin pain model. Prog Neurobiol 1993; 41: 565-607.

21 Jasmin L, Wang H, Tarczy-Hornoch K, Levin JD, Basbaum AI. Differential effects of morphine on noxious stimulus-evoked fos-like immunoreactivity in subpopulations of spinoparabrachial neurons. J Neurosci 1994; 14: 7252-60.

22 Presley RW, Menetrey D, Levine JD, Basbaum AI. Systemic morphine suppresses noxious stimulus-evoked Fos protein-like immunoreactivity in the rat spinal cord. J Neurosci 1990; 10: 323-35.

23 Honore P, Buritova J, Besson JM. Carrageenin-evoked cFos expression in rat lumbar spinal cord: the effects of indomethacin. Eur J Pharmacol 1995; 272: 249-59.

24 Buritova J, Honore P, Besson JM. Ketoprofen produces profound inhibition of spinal c-Fos protein expression resulting from an inflammatory stimulus but not from noxious heat. Pain 1996; 67: 379-89.

25 Jones SL. Noradrenergic modulation of noxious heatevoked fos-like immunoreactivity in the dorsal horn of the rat sacral spinal cord. J Comp Neurol 1992; 325: 435-45.

26 Elliott KJ, Brodsky M, Hynansky AD, Foley KM, Inturrisi CE. Dextromethorphan suppresses both formalin-induced nociceptive behavior and the formalin-induced increase in spinal cord c-fos mRNA. Pain 1995; 61: 401-9.

27 Le Guen S, Catheline G, Besson JM. Effects of NMDA receptor antagonists on morphine tolerance: a cFos study in the lumbar spinal cord of the rat. Eur J Pharmacol 1999; 373: 1-11.

28 Millan MJ. The induction of pain: an integrative review. Prog Neurobiol 1999; 57: 1-164.

29 Berridge CW, Foote SL. Enhancement of behavioral and electroencephalographic indices of waking following stimulation of noradrenergic beta-receptors within the medial septal region of the basal forebrain. J Neurosci 1996; 16: 6999-7009.

30 Hageluken A, Grunbaum L, Nurnberg B, Harhammer $R$, Schunack $W$, Seifert $R$. Lipophilic beta-adrenoceptor antagonists and local anesthetics are effective direct activators of G-proteins. Biochem Pharmacol 1994; 47: 1789-95.

31 Tanabashi S, Iida H, Oda A, Osawa $\Upsilon$, Dohi S. Effect of beta-adrenoceptor antagonists on tetrodotoxinresistant $\mathrm{Na}^{+}$channels in rat dorsal root ganglion neurons. Anesthesiology 2003; A-962 (abstract). 